\title{
BRAND IMAGE MEMEDIASI KUALITAS PRODUK TERHADAP KEPUTUSAN PEMBELIAN PRODUK SMARTPHONE OPPO DI KOTA DENPASAR
}

\author{
I Gusti Ngurah Bagus Hagita Indra Mas Setiadi ${ }^{1}$ \\ Ni Wayan Ekawati ${ }^{2}$ \\ ${ }^{1,2}$ Fakultas Ekonomi dan Bisnis Universitas Udayana, Bali, Indonesia \\ e-mail: indra.setiadi92@gmail.com
}

\begin{abstract}
ABSTRAK
Pengguna smartphone Indonesia bertumbuh dengan pesat. Oppo merupakan salah satu dari sekian banyak produsen smartphone yang memasuki pasar smartphone Indonesia. Tujuan dari penelitian ini adalah untuk menjelaskan pengaruh kualitas produk terhadap brand image, kualitas produk terhadap keputusan pembelian, brand image terhadap keputusan pembelian, serta peran brand image dalam memediasi pengaruh kualitas produk terhadap keputusan pembelian.Teori yang digunakan dalam penelitian ini adalah kualitas produk, brand image dan keputusan pembelian. Penelitian ini dilakukan pada konsumen smartphone Oppo yang berdomisili di Kota Denpasar. Ukuran sampel yang diambil sebanyak 120 orang dengan metode purposive sampling. Teknik analisis yang digunakan adalah analisis path serta uji sobel. Hasil penelitian menemukan bahwa kualitas produk berpengaruh positif dan signifikan terhadap brand image. Penelitian ini juga menemukan bahwa masing-masing variabel kualitas produk dan brand image secara signifikan berpengaruh positif terhadap keputusan pembelian, selain itu brand image juga secara signifikan memediasi hubungan kualitas produk terhadap keputusan pembelian.
\end{abstract}

Kata kunci: kualitas produk, brand image, keputusan pembelian

\begin{abstract}
Indonesian smartphone users are growing rapidly. Oppo is one of the many smartphone manufacturers entering the Indonesian smartphone market. The purpose of this study is to explain the effect of product quality on brand image, product quality to purchase decision, brand image to purchasing decision, and role of brand image in mediating effect of product quality to purchasing decision. The theory used in this research is product quality, brand image and purchase decision. This research was conducted on consumer of Oppo smartphone which domiciled in Denpasar City. The sample size taken as many as 120 people with purposive sampling method. The analysis technique used is path analysis and sobel test. The results of the study found that product quality has a positive and significant effect on brand image. The study also found that each variable of product quality and brand image significantly positively affects purchasing decisions, in addition to the brand image also significantly mediates the relationship of product quality to purchasing decisions.
\end{abstract}

Keyword:product quality, brand image, purchase decisions 


\section{PENDAHULUAN}

Pengguna teknologi smartphonepada negara Indonesia bertumbuh dengan pesat. Lembaga riset digitalmarketing memperkirakan jumlah pengguna aktif smartphone di negara Indonesia lebih dari 100 juta orang pada tahun 2018. Pengguna smartphone dengan jumlah sebesar itu akan menjadikan negara Indonesia sebagai pengguna aktif smartphone terbesar keempat di dunia setelah Cina, India, dan Amerika (Kominfo.go.id, diakses 12 september 2017).

Berkembang pesatnya smartphone di Indonesia karena smartphone dapat mempermudah pekerjaan manusia dalam hal komunikasi atau dalam mencari informasi pada internet. Hasil survei yang dilakukan oleh Asosiasi Penyelenggara Jasa Internet Indonesia (APJII) menunjukan sekitar 98,3\% masyarakat Indonesia menggunakan smartphone dalam mengakses internet. Berikut ini adalah tabel hasil survei yang dilakukan APJII pengguna perangkat telekomunikasi di Indonesia.

Tabel 1.

Pengguna Perangkat Internet

\begin{tabular}{rcc}
\hline $\begin{array}{c}\text { Jumlah } \\
\text { Pengguna }\end{array}$ & Pengguna Perangkat Internet & Persentase \\
\hline 67,2 Juta & Smartphone dan Komputer & 50,7 \\
63,1 Juta & Smartphone & 47,6 \\
2,2 Juta & Komputer & 1,7 \\
\hline Sumber $:$ APJII, 2016 & &
\end{tabular}

Meningkatnya perkembangan teknologi dan sektor telekomunikasi mengakibatkan jumlah pengguna smartphone di seluruh dunia semakin meningkat (Lay-Yee et al., 2013). Berkembang pesatnya industri telekomunikasi khususnya smartphone ini menimbulkan fenomena banyaknya pengguna smartphone sehingga banyak produsen smartphone yang mempromosikan produk-produk 
terbaiknya dalam memenuhi permintaan pasar. Setiap orang akan memilih smartphone yang dapat memenuhi kebutuhan dan keinginannya (Rahim et al., 2016). Konsumen dalam memilih smartphone tentunya akan melakukan berbagai pertimbangan seperti kualitas produk.

Meningkatkan kualitas suatu produk merupakan strategi yang dapat digunakan perusahaan dalam menarik perhatian para konsumen (Saraswati dan Rahyuda, 2017). Konsumen semakin sadar pentingnya kualitas produk dan brandimage karena semakin banyaknya produsen yang bersaing di pasar. Kualitas produk yang baik merupakan salah satu cara yang dapat digunakan bagi perusahaan untuk memenangkan persaingan serta dapat menimbulkan loyalitas terhadap merek pada penggunanya (Dewi dan Suasana, 2014).

Kotler dan Armstrong (2011:273) menyatakan kualitas produk merupakan kemampuan dari suatu produk dalam menjalankan fungsinya yang dapat dilihat dari daya tahan, kehandalan atau kemanjuran, kekuatan, kemudahan dalam pengemasan dan reparasi produk dan ciri-ciri lainnya. Penting bagi produsen untuk terus meningkatkan kualitas produknya karena konsumen sekarang ini lebih pintar dalam menentukan produk yang kualitasnya bagus. Menurut produsen, produk merupakan sesuatu yang harus dikerjakan dengan baik, baik dalam penampilan produk atau kinerja yang dihasilkan (Nurdianto dan Yuniati, 2013). Hal ini berarti dengan peningkatan kualitas produk diharapkan dapat meningkatkan kepuasan bagi konsumen. Meningkatkan kualitas produk sangat penting untuk meningkatkan brand image produk terhadap konsumen karena 
banyaknya produsen smartphone yang akan membuat persaingan semakin ketat di dalam pasar.

Brandimage merupakan aspek penting yang memiliki hubungan dengan produk. Menurut Godey et al. (2012) brand image dapat mempengaruhi persepsi dan sikap konsumen diberbagai kesempatan. Untuk membedakan produk yang satu terhadap produk lainnya walaupun produk tersebut sejenis maka diperlukan sifat khas dalam produk tersebut, sifat khas tersebut dapat dilihat dari brand image produk tersebut (Haryantana dan Ekawati, 2015). Untuk menciptakan nilai yang lebih dipikiran konsumen sehingga akan meningkatkan brand imagemaka produk yang dihasilkan harus baik dan berkualitas (Citra dan Santoso, 2016). Rahi (2016) berpendapat brand image perlu direncanakan, dikembangkan, didukung dan dijaga untuk mendapatkan keunggulan.

Brand image dapat memberikan keuntungan terhadap konsumen karena dapat membantu konsumen dalam mengidentifikasi keuntungan dan kualitas yang dimiliki produk (Ago et al., 2015). Tanzila et al. (2015) berpendapat brand merupakan kepercayaan di mata konsumen sehingga konsumen akan mempercayai kualitas produk terhadap brand yang mereka telah percaya. Brand Image memiliki peran penting dalam mengembangkan brand suatu produk karena brand image memiliki aspek reputasi dan kredibilitas yang akan digunakan konsumen sebagai pertimbangan dalam menggunakan suatu produk maupun jasa (Wijaya, 2013). Konsumen cenderung akan memiliki persepsi yang positif terhadap merek pioner (merek pertama pada suatu kategori produk) meskipun merek lainnya muncul (Suryonaningsih dkk., 2016). 
Pemasar perlu melakukan strategi yang intensif untuk meningkatkan brandimage di hati konsumen. Putra dan Ekawati (2017) berpendapat bahwa brand image yang kuat akan memberikan keunggulan utama bagi perusahaan seperti menciptakan suatu keunggulan bersaing.Brand image merupakan salah satu aspek kuat yang dapat membangun reputasi merek tertentu di pasar sasaran (Durrani et al., 2015). Brandimage yang baik akan berdampak positif bagi perusahaan karena mampu memberikan kepuasan kepada konsumennya, sehingga dapat meningkatkan daya tarik konsumen untuk menggunakan suatu produk (Aristyowati dkk., 2015). Persepsi konsumen juga dapat dipengaruhi oleh citra yang baik sehingga citra yang baik merupakan salah satu aset perusahaan (Arimbawa dan Ekawati, 2017). Kualitas produk dan brand image merupakan hal yang akan diperhatikan oleh konsumen dalam mengambil keputusan pembelian.

Keputusan untuk membeli dipengaruhi berbagai macam dorongan (Amrullah dkk., 2016). Keputusan pembelian konsumen terhadap produk yang ditawarkan oleh produsen juga dipengaruhi oleh bauran pemasaran seperti persepsi harga, produk, promosi dan tempat (Widyastutir dan Said, 2017). Brand suatu produk juga sangat diperhatikan konsumen dalam mengambil keputusan pembelian karena konsumen ketika membeli barang cenderung mempertimbangkan brand terkenal dan berkualitas tinggi untuk mengurangi risiko masalah setalah pembelian (Momani, 2015). Konsumen akan terus mengambil berbagai keputusan setiap hari tetapi konsumen terkadang mengambil keputusan ini tanpa memikirkan bagaimana mengambil keputusan dan apa yang terlibat dalam pengambilan keputusan tersebut (Sari dkk., 2015). Konsumen akan 
menghadapi tugas untuk mengevaluasi banyak produk/layanan serupa sebelum memilih produk tertentu (Yeboah et al., 2017).

Keputusan pembelian adalah tahapan proses penyelesaian masalah yang terdiri dari pengenalan masalah, mencari informasi, beberapa penilaian alternative, membuat keputusan membeli, dan perilaku setelah membeli yang dilalui konsumen (Kotler dan Keller, 2012:184). Pemasar harus dapat menunjukan keunggulan produknya kepada konsumen agar konsumen merasa yakin untuk mengambil keputusan pembelian. Konsumen yang merasa puas atas keputusan pembeliannya pada suatu produk akan memberitahu manfaat dari produk tersebut saat seseorang meminta pendapat terhadap produk tersebut atau mengukapkan pendapat dimedia sosial untuk mengukap kepuasan mereka (Susanti, 2017).

Sipayung dan Sinaga (2017) menyatakan keputusan pembelian konsumen adalah pemikiran yang dilakukan konsumen untuk merencanakan pembelian beberapa produk dengan merek tertentu. Konsumen dalam mengambil keputusan pembelian tentu akan melakukan banyak pertimbangan seperti kualitas produk dan brand image produk yang akan dibeli konsumen tersebut. Penelitian yang dilakukan Rosyid dkk. (2013) menunjukan kualitas produk memiliki pengaruh positif terhadap keputusan pembelian sepeda motor Honda Revo pada konsumen Astra Motor Kebumen. Penelitian lain yang dilakukan Rohmah dan Kuzaini (2015) menyatakan brand image berpengaruh signifikan terhadap keputusan pembelian produk perhiasan. Kualitas produk dan brand image yang memiliki pengaruh terhadap keputusan pembelian juga terjadi pada produk lainnya seperti produk smartphone. 
I Gusti Ngurah Bagus Hagita Indra Mas Setiadi, BrandImage Memediasi....

Smartphone merupakan teknologi yang sangat diperlukan bagi sebagian besar masyarakat diseluruh dunia sehingga banyak produsen smartphone yang bersaing dalam meningkatkan pangsa pasarnya. Pengukuran penjualan smartphone dapat dilihat dari seberapa banyak konsumen yang melakukan keputusan pembelian terhadap merek smartphone tertentu (Ruslim dan Tumewu, 2015). Berikut adalah data globalmarket share terbaru yang diperoleh dari Statista yang ditampilkan pada Tabel 2.

Tabel 2.

Global Market Share Smartphone Vendors

\begin{tabular}{lccc}
\hline \multirow{2}{*}{ Merek } & \multicolumn{3}{c}{ Tahun } \\
\cline { 2 - 4 } & $\mathbf{2 0 1 5}$ & $\mathbf{2 0 1 6}$ & $\mathbf{2 0 1 7}$ \\
\hline Samsung & $20,4 \%$ & $18 \%$ & $18.4 \%$ \\
Apple & $18,7 \%$ & $18,2 \%$ & $19.2 \%$ \\
Huawei & $8,2 \%$ & $10,5 \%$ & $10.2 \%$ \\
Oppo & $3,6 \%$ & $7,3 \%$ & $6.8 \%$ \\
Xiaomi & $4,6 \%$ & $3,3 \%$ & $7 \%$ \\
\hline
\end{tabular}

Sumber : Statista, 2018

Berdasarkan Tabel 2 yang menunjukan bahwa produsen besar pada industri smartphone merupakan Samsung dan Apple, hal ini dapat dilihat dari perolehan market share yang paling banyak daripada pesaing lainnya. Market leader pada tahun 2017 adalah Apple setelah berhasil merebut market share Samsung pada tahun 2016 dan 2017. Huawei dapat mempertahankan market share yang dimilikinya pada kisaran 10 persen mesikipun mengalami penurunan 0,3 persen dari tahun 2016 sampai tahun 2017. Xiaomi dapat meningkatkan market share yang dimilikinya dengan cukup tinggi dari 3,3 persen hingga 7 persen pada tahun 
2016 sampai 2017. Hal ini mengindikasikan bahwa produk Xiaomi mulai dapat diterima dengan baik oleh konsumen. Oppo mengalami pertumbuhan market share yang tinggi di tahun 2016 yang berarti tingginya minat konsumen terhadap produk smartphone Oppo tetapi pada tahun 2017 market share Oppo mengalami penurunan yang mengindikasikan produk yang ditawarkan Oppo mulai kalah bersaing dengan merek lainnya. Menurunnya market share Oppo juga disebabkan oleh perubahan pada strategi salurannya dengan menjadi lebih selektif terhadap mitra ritelnya (International Data Corporation, 2018). Adanya penurunan market share ini, Oppo harus mengembangkan strategi pemasarannya untuk dapat bersaing di pasar internasional, tidak terkecuali pada Negara Indonesia.

Persaingan produk smartphone pada Negara Indonesia sangatlah ketat dengan adanya berbagai produsen smartphone yang memasuki pasar Indonesia. Melihat hasil survei Top Brand Award merupakan cara yang dapat digunakan untuk melihat produk smartphone yang diminati pada pasar Indonesia. Penilaian yang digunakan Top Brand Award dalam menentukan Top Brand adalahdengan cara membandingkan indikator mind share, market share dan commitment share suatu produk dengan jenis produk yang sama. Smartphone yang diminati pada pasar Indonesia dapat dilihat dari hasil survei terbaru Top Brand Award kategori smartphone pada Tabel 3. 
Tabel 3.

Top Brand Fase 1 Kategori Smartphone 2018

\begin{tabular}{cc}
\hline Merek & TBI \\
\hline Samsung & $48,6 \%$ \\
Oppo & $11,2 \%$ \\
Xiaomi & $5,5 \%$ \\
Lenovo & $4,5 \%$ \\
Nokia & $4,3 \%$ \\
\hline
\end{tabular}

Sumber :Top Brand Award, 2018

Tabel 3 menunjukan bahwa Samsung merupakan Top Brand nomor 1 Indonesia. Hal ini dikarenakan Samsung merupakan produsen smartphone yang besar dan sudah bermain cukup lama pada industri smartphone khususnya pada pasar Indonesia. Posisi Top Brand nomor 2 ditempati oleh merek Oppo yang mampu membangun brand image yang baik dalam waktu 5 tahun semenjak memasuki pasar Indonesia pada tahun 2013. Hal ini menunjukan produk smartphone Oppo mampu memberikan kesan yang baik di benak konsumen sehingga mampu memperoleh Top Brand nomor 2 mengalahkan Xiaomi, Lenovo, dan Nokia di awal tahun 2018 walaupun pada tahun 2017 Oppo mengalami penurunan market share pada pasar internasional.

Kesuksesan Oppo dalam mempertahankan brand image yang dimilikinya tidak terlepas dari inovasi dan mengikuti trend permintaan pasar, seperti trend smartphone dengan layar besar dan memiliki kamera yang mampu menghasilkan foto selfie dengan jernih (Oppo F5). Berkembangnya industri telekomunikasi yang cepat, Oppo harus mampu dalam mengembangkan brandimage dan kualitas produk agar mampu bersaing dengan pesaing lainnya. Melakukan pengembangan 
brandimage dan kualitas produk diharapkan dapat mempengaruhi konsumen dalam mengambil langkah untuk melakukan keputusan pembelian. Adanya fenomena kesuksesan smartphone Oppo yang baru memasuki pasar smartphone Indonesia tetapi dalam waktu 5 tahun berhasil menjadi berhasil menjadi top brand peringkat 2 di tahun 2018 walaupun pada tahun 2017 smartphone Oppo mengalami penurunan market share di pasar internasional sehingga merek smartphone Oppo dianggap menarik menjadi subjek penelitian.

Berdasarkan penelitian terdahulu, Rosyid dkk. (2013) menyatakan kualitas produk memiliki pengaruh positif terhadap keputusan pembelian. Berbeda dengan penelitian yang dilakukan Supriyadi dkk. (2016) yang menyatakan kualitas produk tidak berpengaruh terhadap keputusan pembelian. Terjadinya perbedaan penelitian tersebut menimbulkan penggunaan brand image sebagai mediasi yang didukung oleh penelitian Sarasawati dan Rahyuda (2017) yang menunjukan brandimage dinilai secara signifikansi memediasi kualitas produk dengan keputusan pembelian.

Berdasarkan fenomena, hasil wawancara dan research gap yang telah dipaparkan pada latar belakang ini, maka penelitian ini membahas mengenai “BrandImage Memediasi Kualitas Produk Terhadap Keputusan Pembelian Produk Smartphone Oppo di Kota Denpasar".

Berdasarkan latar belakang serta fenomena yang telah disebutkan, maka dapat disusun beberapa rumusan masalah antara lain: 1) bagaimanakah pengaruh kualitas produk terhadap brand image pada produk smartphone Oppo di Kota Denpasar?, 2) bagaimanakah pengaruh kualitas produk terhadap keputusan 
pembelian pada produk smartphone Oppo di Kota Denpasar?, 3) bagaimanakah pengaruh brand image terhadap keputusan pembelian pada produk smartphone Oppo di Kota Denpasar?, 4) bagaimanakah peran brand image dalam memediasi hubungan kualitas produk dengan keputusan pembelian pada produk smartphone Oppo di Kota Denpasar?

Kemudian, tujuan dari penelitian ini adalah: 1) Untuk menjelaskan pengaruh kualitas produk terhadap brand image pada produk smartphone Oppo di Kota Denpasar. 2) Untuk menjelaskan pengaruh kualitas produk terhadap keputusan pembelian pada produk smartphone Oppo di Kota Denpasar. 3) Untuk menjelaskan pengaruh brand image terhadap keputusan pembelian pada produk smartphone Oppo di Kota Denpasar. 4) Untuk menjelaskan peran brand image dalam memediasi hubungan kualitas produk dengan keputusan pembelian pada produk smartphone Oppo di Kota Denpasar.

Penelitian ini diharapkan nantinya mampu memperjelas peran brand image dalam memediasi hubungan kualitas produk dengan keputusan pembelian konsumen serta penelitian ini diharapkan dapat menambah referensi yang dapat digunakan untuk penelitian selanjutnya, khususnya tentang brand image. Selain itu, penelitian ini juga diharapkan dapat digunakan sebagai bahan pertimbangan dari pihak OPPO Electronics Corp, Ltd. dalam merumuskan kebijakan-kebijakan yang berkaitan dengan kualitas produk, brand image, dan keputusan pembelian konsumen, sehingga nantinya dapat meningkatkan kinerja bisnisnya. 
Adapun hipotesis dalam penelitian ini antara lain:

$\mathrm{H}_{1}$ : Kualitas produk berpengaruh positif dan signifikan terhadap brand image.

Kualitas produk merupakan salah satu variabel penting yang mempengaruhi brand image. Peningkatan kualitas produk merupakan salah cara untuk mempertahankan brand image produk tersebut (Rohmah dan Khuzaini, 2015). Hal ini berarti dengan peningkatan kualitas produk dapat meningkatan kesan terhadap brand image produk tersebut.

Penelitian yang dilakukan sebelumnya oleh Nurdianto dan Yuniati (2013) menunjukan pengaruh positif dan signifikan antara kualitas produk dengan brandimage motor honda. Kualitas produk memiliki pengaruh yang positif terhadap brandimage sepeda motor merek Kawasaki di dalam penelitian Noerchoidah (2013). Penelitian yang dilakukan oleh Supangkat dan Supriyatin (2017) menunjukan hasil bahwa kualitas produk berpengaruh signifikan terhadap keputusan pembelian tas di Intako. Hestyani dan Astuti (2017) dalam penelitiannya menyatakan kualitas produk berpengaruh positif dan signifikan terhadap brand image Mustika Ratu. Berbeda dengan hasil penelitian yang dilakukan oleh Nuraini dan Maftukhah (2015) yang menyatakan secara langsung kualitas produk tidak berpengaruh terhadap brand image kosmetik Wardah.

$\mathrm{H}_{2}$ : Kualitas produk berpengaruh positif dan signifikan terhadap keputusan pembelian.

Kualitas produk merupakan salah satu aspek yang diperhatikan konsumen dalam mengambil keputusan pembelian. Kualitas produk yang baik akan memberikan kepercayaan kepada konsumen yang akan menjadi motivasi bagi konsumen untuk membeli produk tersebut (Nurdianto dan Yuniati, 2013). Hal ini 
I Gusti Ngurah Bagus Hagita Indra Mas Setiadi, BrandImage Memediasi....

berarti kualitas produk yang baik dapat memberikan kepuasan bagi konsumen setelah konsumen tersebut melakukan keputusan pembelian produk tersebut.

Penelitian yang dilakukan Rares dan Jorie (2015) menunjukan kualitas produk berpengaruh signifikan terhadap keputusan pembelian konsumen di Bengkel Gaoel Manado TownSquare. Hasil penelitian Rosyid dkk. (2013) menunjukan kualitas produk memiliki pengaruh positif terhadap keputusan pembelian sepeda motor Honda Revo pada konsumen Astra Motor Kebumen. Penelitian yang dilakukan Sari dkk. (2015) juga menunjukan kualitas produk berpengaruh positif dan signifikan terhadap keputusan pembelian lemari es merek LG. Penelitian lainnya yang dilakukan Alfred (2013) mendapatkan hasil bahwa kualitas produk menunjukan pengaruh yang positif dan signifikan terhadap keputusan pembelian smartphone di kota Kumasi. Berbeda dengan penelitian yang dilakukan Supriyadi dkk. (2016) yang menunjukan kualitas produk tidak berpengaruh terhadap keputusan pembelian pada produk sepatu merek Converse. Penelitian yang dilakukan oleh Anastasia dan Nurendah (2014) menyatakan kualitas produk memiliki pengaruh negatif dan tidak signifikan terhadap keputusan pembelian konsumen Teh Botol Sosro.

$\mathrm{H}_{3}$ : Brand image berpengaruh positif dan signifikan terhadap keputusan pembelian.

Brand image sangat berperan terhadap keputusan pembelian. Hal ini dikarenakan ketika konsumen sudah menyukai suatu merek maka konsumen tersebut akan membeli produk dari merek tersebut dengan tidak berpikir dua kali (Rawung dkk., 2015). Penting bagi perusahan untuk membangun brand 
imagesehingga menimbulkan kepercayan bagi konsumen untuk melakukan keputusan pembelian suatu produk.

Rohmah dan Kuzaini (2015) dalam penelitiannya menyatakan brand image berpengaruh signifikan terhadap keputusan pembelian produk perhiasan. Penelitian yang dilakukan Amrullah dkk. (2016) menyatakan brandimage berpengaruh signifikan secara positif terhadap keputusan pembelian Honda Beat. Aristyowati dkk. (2015) dalam penelitianya memperoleh hasil bahwa brandimage berpengaruh positif dan signifikan terhadap keputusan pembelian OBH Combi di farmasi Semarang. Selain itu, penelitian yang dilakukan oleh Citra dan Santoso (2016) menyatakan brandimage berpengaruh positif dan signifikan terhadap keputusan pembelian pada konsumen Percetakan Jadi Jaya Group. Perbedaan hasil penelitian ditemukan oleh Nurhayati (2017) menyatakan brand image tidak berpengaruh terhadap keputusan pembelian smartphone Samsung. Parengkuan dkk. (2014) menyatakan brand image tidak berpengaruh signifikan terhadap keputusan pembelian Shampo Head and Shoulders.

$\mathrm{H}_{4}$ : Brand image berpengaruh positif dan signifikan dalam memediasi kualitas produk dengan keputusan pembelian.

Kualitas produk yang baik bertujuan untuk menimbulkan kepuasan pada diri konsumen. Apabila konsumen merasa puas, maka konsumen tersebut akan melakukan pembelian ulang yang akan meningkatkan keputusan pembelian. Brand image juga membantu suatu produk untuk mendapatkan konsumennya karena apabila brand image yang dimiliki produk sangat kuat tentu akan mengakibatkan persepsi merek yang terbenak dalam diri konsumen menjadi baik sehingga konsumen merasa yakin dalam mengambil keputusan pembelian produk 
tersebut. Brand image berperan sebagai pemediasi untuk meningkatkan hubungan antara kualitas produk dan keputusan pembelian.

Penelitian yang dilakukan Saraswati dan Rahyuda (2017) menunjukan brandimage dinilai secara signifikansi memediasi kualitas produk dengan keputusan pembelian smartphone Apple di Kota Denpasar. Nurdianto dan Yuniati (2013) dalam penelitianya memperoleh hasil bahwa kualitas produk berpengaruh positif dan signifikan terhadap keputusan pembelian dengan brandimage sebagai variabel intervening. Parasayu dan Widayanto (2016) dalam penelitiannya menunjukan kualitas produk berpengaruh positif terhadap keputusan pembelian dengan brand image sebagai variabel interverning pada produk Indomie Goreng. Penelitian Situmorang dkk. (2017) menyatakan kualitas produk memiliki pengaruh yang kuat terhadap keputusan pembelian kosmetik kecantikan merek Ponds dengan brand image sebagai variabel moderasi.Perbedaan hasil penelitian ditemukan oleh Laura.S dan Ringo (2017) dengan hasil brand image tidak mampu memediasi secara positif signifikan kualitas produk terhadap keputusan pembelian.

\section{METODE PENELITIAN}

Penelitian ini dilakukan di Kota Denpasar. Kota Denpasar dijadikan sebagai lokasi penelitian dengan pertimbangan Kota Denpasar merupakan ibukota Provinsi Bali dan terdapat banyak masyarakat yang menggunakan berbagai jenis smartphone pada kota Denpasar sehingga sangat mudah untuk menemukan responden yang sesuai dengan kategori yang diteliti. 
Data yang digunakan dalam penelitian ini dibagi menjadi dua yaitu berdasarkan jenis data dan sumber data. Berdasarkan jenis datanya dibagi menjadi data kuantitatif yaitu hasil tabulasi dari kuesioner yang telah dijawab dari pertanyaan-pertanyaan kuesioner oleh responden dan data kualitatif yaituwawancara secara langsung kepada konsumen yang telah melakukan pembelian terhadap smartphone Oppo di Kota Denpasar untuk mendapat penilaian tentang baik atau tidaknya kualitas produk dan brand image yang dikatakan secara langsung maupun tidak langsung oleh konsumen.. Berdasarkan sumber datanya, dalam penelitian ini dibagi menjadi 2 yaitu data primer dalam penelitian ini diperoleh langsung dari hasil penyebaran kuesioner terhadap responden yang pernah melakukan pembelian smartphone Oppo serta masih menggunakan smartphone Oppo tersebut dan data sekunder dalam penelitian ini adalah data dari studi empiris yang telah dilakukan oleh peneliti sebelumnya yang berkaitan dengan kualitas produk, brand image dan keputusan pembelian.

Pada penelitian ini, terdapat 3 jenis variabel data yang digunakan antara lain: variabel eksogen yaitu kualitas produk (X), variabel mediasi yaitu brand image $\left(\mathrm{Y}_{1}\right)$, dan variabel endogen yaitu keputusan pembelian $\left(\mathrm{Y}_{2}\right)$.Populasi dalam penelitian ini adalah konsumen smartphone Oppo. Populasi dalam penelitian ini bersifat infinite (tidak terbatas). Sampel dalam penelitian ini adalah konsumen yang melakukan pembelian terhadap produk smartphone Oppo dan masih menggunakan smartphone Oppo tersebut. Teknik penentuan sampel yang digunakan pada penelitian ini adalah non probability sampling dengan metode purposive sampling, yaitu sampel ditentukan dengan pertimbangan 
tertentu.Menurut Sugiyono (2017:156) untuk memperoleh hasil yang baik ukuran sampel responden yang diambil untuk mengisi kuesioner dapat ditentukan paling sedikit 5 - 10 kali jumlah indikator yang diteliti. Penelitian ini menggunakan 12 indikator sehingga dengan menggunakan estimasi berdasarkan jumlah parameter diperoleh ukuran sampel sebesar 60 - 120 responden. Jumlah dari sampel responden yang akan diuji di dapat dari hasil perhitungan sebagai berikut : Jumlah Responden $=12$ indikator $\mathrm{x} 10=120$ responden . Berdasarkan perhitungan tersebut maka penelitian ini mengambil sampel sebanyak 120 responden, selain itu jumlah sampel tersebut sesuai dengan metode yang digunakan yaitu path analysis karena dalam penelitian yang menggunakan metode path analysis sampel yang digunakan harus minimal 100 sampel. Menurut Roscoe dalam Sekaran (2003) parameter sampel yang baik adalah sekitar 70-140 sampel. Jadi, dengan dipilihnya 120 responden artinya sudah sesuai dengan kriteria yang ditentukan. Kriteria penentuan sampel dalam penelitian ini adalah: 1) Berdomisili di Kota Denpasar, 2) Pendidikan terakhir minimal SMA/SMK sederajat, 3) Responden yang pernah melakukan pembelian terhadap produk smartphone Oppo dan masih menggunakan produk smartphone Oppo tersebut.

Metode pengumpulan data yang digunakan dalam penelitian ini adalah kuesioner. Kuesioner dibuat dengan menggunakan pertanyaan terbuka, yaitu terdiri dari pertanyaan-pertanyaan untuk menjelaskan identitas responden, dan pertanyaan tertutup, yaitu pertanyaan yang meminta responden untuk memilih salah satu jawaban yang tersedia dari setiap pertanyaan. Pertanyaan dalam kuesioner dibuat dengan menggunakan skala Likert.Teknik analisis data yang 
digunakan dalam penelitian ini adalah teknik analisis jalur (path analysis) dan uji sobel.

\section{HASIL PENELITIAN}

Berdasarkan hasil karakterisitik responden diperoleh data yaitu dalam penelitian ini reponden dengan jenis kelamin laki-laki lebih banyak dalam melakukan pembelian smartphone Oppo dengan persentase 53,3 persen diikuti responden berjenis kelamin wanita 46,7 persen. Responden terbanyak dalam variabel usia adalah 22-26 tahun dengan persentase sebesar 41,7 persen dikarenakan pada rentang usia ini responden dianggap lebih mengerti dalam memilih produk yang memiliki kualitas dan brand image yang baik. Peringkat kedua ditempati oleh usia 17-21 tahun dengan persentase 28,3 persen. Peringkat ketiga ditempati oleh responden berusia diatas 42 tahun sebesar 11,7 persen kemudian usia 27-31 menempati posisi keempat dengan persentase 9,1 persen. Posis kelima ditempati usia 37-42 tahun dengan persentase 5 persen dan usia 3236 menempati posisi terakhir dengan persentase 4,2 persen. Pekerjaan dari responden memperlihatkan bahwa reponden didominasi oleh pelajar atau mahasiswa sebesar 54,1 persen selanjutnya diikuti oleh responden berprofesi sebagai karyawan swasta dengan persentase sebesar 25,8 persen. Profesi PNS menempati urutan ketiga dengan jumlah sebesar 10 persen diikuti oleh profesi pengusaha pada urutan keempat dengan persentase sebesar 6,8 persen dan urutan terakhir ditempati profesi lain-lain yaitu ibu rumah tangga dengan persentase sebesar 3,3 persen. Hal ini mengindikasikan jika pelajar atau mahasiswa lebih 
memilih produk smartphone yang memiliki kualitas produk dan brand image yang baik.

Uji validitas bertujuan untuk memeriksa apakah indikator pada kuesioner sebagai alat ukur sudah tepat sehingga mendapatkan hasil yang valid. Hasil uji validitas instrumen penelitian telah disajakan pada Tabel 4.

Tabel 4. Uji Validitas

\begin{tabular}{cccc}
\hline Variabel & Instrumen & $\begin{array}{c}\text { Pearson } \\
\text { Correlation }\end{array}$ & Keterangan \\
\hline \multirow{3}{*}{ Kualitas Porduk $(\mathrm{X})$} & $\mathrm{X}_{1.1}$ & 0,556 & Valid \\
& $\mathrm{X}_{1.2}$ & 0,823 & Valid \\
& $\mathrm{X}_{1.3}$ & 0,723 & Valid \\
& $\mathrm{X}_{1.4}$ & 0,797 & Valid \\
\hline \multirow{3}{*}{ Brand Image (Y1) } & $\mathrm{Y}_{1.1}$ & 0,783 & Valid \\
& $\mathrm{Y}_{1.2}$ & 0,723 & Valid \\
& $\mathrm{Y}_{1.3}$ & 0,822 & Valid \\
& $\mathrm{Y}_{1.4}$ & 0,584 & Valid \\
& $\mathrm{Y}_{1.5}$ & 0,833 & Valid \\
\hline \multirow{3}{*}{ Keputusan Pembelian (Y2) } & $\mathrm{Y}_{2.1}$ & 0,874 & Valid \\
& $\mathrm{Y}_{2.2}$ & 0,825 & Valid \\
& $\mathrm{Y}_{3.3}$ & 0,785 & Valid \\
\hline
\end{tabular}

Sumber : Data Diolah, 2018

Instrumen dapat dikatakan reliabel jika instrumen tersebut memiliki nilai Alpha Cronbach lebih dari 0,70. Hasil uji reliabilitas dapat dilihat pada Tabel 5.

Tabel 5.

Uji Reliabilitas

\begin{tabular}{ccc}
\hline Variabel & Cronbadh's Alpha & Keterangan \\
\hline Kualitas Produk $(\mathrm{X})$ & 0,705 & Reliabel \\
Brand Image $\left(\mathrm{Y}_{1}\right)$ & 0,802 & Reliabel \\
Keputusan Pembelian $\left(\mathrm{Y}_{2}\right)$ & 0,772 & Reliabel \\
\hline
\end{tabular}

Sumber : Data Diolah, 2018

Pengujian data dalam penelitian ini mengunakan teknik analisis jalur (path analysis), yaitu teknik perluasan dari analisis regresi linear berganda untuk 
menguji hubungan kausalitas antara 2 atau lebih variabel. Hasil pengujian menggunakan teknis analisi jalur dapat dilihat pada tabel berikut :

\section{Tabel 6.}

Hasil Analisis Jalur Persamaan Regresi 1

\begin{tabular}{cccccc}
\hline Model & \multicolumn{2}{c}{$\begin{array}{c}\text { Unstandardized } \\
\text { Coefficients }\end{array}$} & $\begin{array}{c}\text { Standardized } \\
\text { Coefficients }\end{array}$ & T & \multirow{2}{*}{ Sig. } \\
\cline { 2 - 4 } & $\mathbf{B}$ & Std.Error & Beta & & \\
\hline 1 (Constant) Kualitas & 9.496 & 1.457 & & 6.516 & .000 \\
Produk & .663 & .087 & .575 & 7.631 & .000 \\
\hline R1 Square & & & & 0,330 \\
F Statistik & & & & 58,232 \\
Signifikansi & & & & 0,000 \\
\hline
\end{tabular}

Sumber : Data Diolah, 2018

Berdasarkan hasil analisis jalur substruktur 1 pada Tabel 6, maka persamaan strukturalnya adalah sebagai berikut.

$$
\begin{aligned}
& \mathrm{Y}_{1}=\beta_{1} \mathrm{X}+\varepsilon_{1} \ldots \ldots \\
& \mathrm{Y}_{1}=0,575 \mathrm{X}+\varepsilon_{1}
\end{aligned}
$$

Nilai $\beta_{1}$ adalah sebesar 0,575 memiliki arti bahwa kualitas produk berpengaruh positif terhadap brand image, dengan kata lain jika faktor kualitas produk meningkat maka akan mengakibatkan peningkatan pada brand imagesmartphone Oppo sebesar 0,575.

Tabel 7.

\begin{tabular}{|c|c|c|c|c|c|}
\hline \multirow[t]{2}{*}{ Model } & \multicolumn{2}{|c|}{$\begin{array}{c}\text { Unstandardized } \\
\text { Coefficients }\end{array}$} & \multirow{2}{*}{$\begin{array}{c}\begin{array}{c}\text { Standardized } \\
\text { Coefficients }\end{array} \\
\text { Beta }\end{array}$} & \multirow[t]{2}{*}{$\mathbf{T}$} & \multirow[t]{2}{*}{ Sig. } \\
\hline & B & Std.Error & & & \\
\hline 1 (Constant) Kualitas & -.007 & .983 & & -.007 & .995 \\
\hline Produk & .237 & .061 & .283 & 3.855 & .000 \\
\hline Brand Image & .408 & .053 & .562 & 7.664 & .000 \\
\hline R1 Square & & & & & 0,579 \\
\hline F Statistik & & & & & 80,316 \\
\hline Signifikansi & & & & & 0,000 \\
\hline
\end{tabular}

Hasil Analisis Jalur Persamaan Regresi 2

Sumber : Data Diolah, 2018 
Berdasarkan hasil analisis jalur substruktur 2 pada Tabel 7, maka persamaan strukturalnya adalah sebagai berikut :

$$
\begin{aligned}
& \mathrm{Y}_{2}=\beta_{2} \mathrm{X}+\beta_{3} \mathrm{Y} 1+\varepsilon_{2} \ldots \ldots \ldots \ldots \\
& \mathrm{Y}_{2}=0,283 \mathrm{X}+0,562 \mathrm{Y} 1+\varepsilon_{2}
\end{aligned}
$$

Nilai $\beta_{2}$ adalah sebesar 0,283 memiliki arti bahwa kualitas produk berpengaruh positif terhadap keputusan pembelian, dengan kata lain jika faktor kualitas produk meningkat maka akan mengakibatkan peningkatan pada keputusan pembelian smartphone Oppo sebesar 0,283.

Nilai $\beta_{3}$ adalah sebesar 0,562 memiliki arti bahwa brand image berpengaruh positif terhadap keputusan pembelian, dengan kata lain jika faktor brand image meningkat maka akan mengakibatkan peningkatan pada keputusan pembelian smartphone Oppo sebesar 0,562.

Berdasarkan Tabel 6 dan Tabel 7maka dapat disusun Tabel 8 yaitu tabel mengenai Pengaruh Langsung dan Pengaruh Tidak Langsung serta Pengaruh Total Kualitas Produk (X), Brand Image $\left(\mathrm{Y}_{1}\right)$, Keputusan Pembelian $\left(\mathrm{Y}_{2}\right)$.

Tabel 8.

Pengaruh Langsung dan Pengaruh Tidak Langsung serta Pengaruh Total Kualitas Produk (X), Brand Image $\left(\mathrm{Y}_{1}\right)$, dan Keputusan Pembelian $\left(\mathrm{Y}_{2}\right)$

\begin{tabular}{cccc}
\hline $\begin{array}{c}\text { Pengaruh } \\
\text { Variabel }\end{array}$ & $\begin{array}{c}\text { Pengaruh } \\
\text { Langsung }\end{array}$ & $\begin{array}{c}\text { Pengaruh Tidak Langsung Melalui } \\
\text { Brand Image } \\
\left(\mathbf{Y}_{\mathbf{1}}\right)\left(\boldsymbol{\beta}_{\mathbf{1}} \mathbf{x} \boldsymbol{\beta}_{3}\right)\end{array}$ & Pengaruh Total \\
\hline $\mathrm{X} \rightarrow \mathrm{Y}_{1}$ & 0,575 & - & 0,575 \\
$\mathrm{X} \rightarrow \mathrm{Y}_{2}$ & 0,283 & 0,323 & 0,606 \\
$\mathrm{Y}_{1} \rightarrow \mathrm{Y}_{2}$ & 0,562 & - & 0,562 \\
\hline \multicolumn{4}{l}{ Sumber : Data } \\
Diolah, 2018
\end{tabular}

Hasil pada tabel 8 menunjukan bahwa pengaruh langsung variabel kualitas produk terhadap keputusan pembelian memiliki nilai koefisien beta sebesar 0,283 
namun pengaruh tidak langsung yang dimediasi oleh brand image menunjukan nilai koefisien beta sebesar 0,323. Ini membuktikan bahwa brand image memediasi kualitas produk terhadap keputusan pembelian dengan pengaruh total yang diperoleh adalah sebesar 0,606.

Uji sobel merupakan alat analisis yang digunakan untuk menguji signifikansi dari hubungan tidak langsung antara variabel independen dengan variabel dependen yang dimediasi oleh variabel mediator. Hasil uji sobel dapat dilihat pada Tabel 9.

Tabel 9.

Hasil Uji Sobel

\begin{tabular}{ccc}
\hline Sobel & Nilai & Keterangan \\
\hline $\mathrm{Z}$ & 5,5910 & Memediasi \\
Sig. & 0,000 & Signifikansi \\
\hline
\end{tabular}

Sumber : Data Diolah,2018

Hasil dari pengujian variabel mediasi pada Tabel 9 yaitu brand image didapatkan $\mathrm{Z}$ hitung sebesar 5,5910>1,96 dengan tingkat signifikan sebesar $0,000<0.05$ yang berarti $\mathrm{H}_{0}$ ditolak dan $\mathrm{H}_{1}$ diterimayang berarti variabel brand image dinilai secara signifikan memediasi variabel kualitas produkpada keputusan pembelian smartphone Oppo di Denpasar.

Pengujian hipotesis pada pengaruh kualitas produk terhadap brand image menunjukkan bahwa kualitas produk secara signifikan berpengaruh positif terhadap brand image. Hal tersebut menunjukan semakin baiknya kualitas produk yang diberikan oleh smartphone Oppo maka akan meningkatkan brand image dari smartphone Oppo di Kota Denpasar. Hasil penelitian ini mendukung penelitian dari Nurdianto dan Yuniati (2013), Noerchoidah (2013), Supangkat dan 
I Gusti Ngurah Bagus Hagita Indra Mas Setiadi, BrandImage Memediasi....

Supriyatin (2017), Arindita dan Sulistyaningtyas (2013), Hestyani dan Astuti (2017) yang menjelaskan bahwa kualitas produk berpengaruh positif dan signifikan terhadap brand image. Hal ini menunjukan jika kualitas produk yang ditawarkan semakin baik maka brand image produk tersebut akan meningkat juga.

Pengujian hipotesis pada pengaruh kualitas produk terhadap keputusan pembelian menunjukkan bahwa kualitas produk secara signifikan berpengaruh positif terhadap keputusan pembelian. Hal tersebut menunjukan semakin baiknya kualitas produk yang diberikan oleh smartphone Oppo maka akan meningkatkan keputusan pembelian smartphone Oppo di Kota Denpasar. Hasil penelitian ini mendukung temuan dari Rares dan Jorie (2015), Rosyid dkk. (2013), Sari dkk. (2015), dan Alfred (2013) yang menjelaskan bahwa kualitas produk berpengaruh positif dan signifikan terhadap keputusan pembelian. Hal ini menunjukan bahwa kualitas produk merupakan salah satu faktor yang harus diperhatikan dalam meningkatkan keputusan pembelian suatu produk.

Pengujian hipotesis pada pengaruh brand image terhadap keputusan pembelian menunjukkan bahwa brand image secara signifikan berpengaruh positif terhadap keputusan pembelian. Hal tersebut menunjukan semakin baiknya brand image yang dimiliki oleh smartphone Oppo maka akan meningkatkan keputusan pembelian smartphone Oppo di Kota Denpasar. Hasil penelitian ini mendukung temuan dari Rohmah dan Kuzaini (2015), Amrullah dkk. (2016), Aristyowati dkk. (2015), dan Citra dan Santoso (2016) yang menjelaskan bahwa brand image berpengaruh positif dan signifikan terhadap keputusan pembelian. 
Hal ini menunjukan bahwa perlunya untuk menjaga dan meningkatkan brand image karena dapat mempengaruhi pengambilan keputusan pembelian konsumen akan suatu produk.

Pengujian hipotesis pada peran brand image dalam memediasi kualitas produk terhadap keputusan pembelian menunjukkan bahwa brand image mampu memediasi pengaruh kualitas produk terhadap keputusan pembelian. Hal ini menunjukan brand image memediasi pengaruh kualitas produk terhadap keputusan pembelian secara parsial, dengan kata lain brand image memperkuat pengaruh kualitas produk terhadap keputusan pembelian yang semula bernilai 0,302 namun setelah adanya brand image sebagai variabel mediasi pengaruh kualitas produk terhadap keputusan pembelian meningkat menjadi 0,585. Hasil penelitian ini mendukung temuan dari Saraswati dah Rahyuda (2017), Nurdianto dan Yuniati (2013), Parasayu dan Widayanto (2016) yang menjelaskan bahwa brand image berperan sebagai variabel mediasi antara kualitas produk dan keputusan pembelian.

\section{SIMPULAN DAN SARAN}

Berdasarkan hasil pembahasan dalam penelitian yang telah dilakukan, maka dapat ditarik beberapa kesimpulan antara lain: pertama, kualitas produk secara signifikan berpengaruh positif terhadap brand image produk smartphone Oppo di Kota Denpasar. Hal tersebut menyimpulkan semakin baiknya kualitas produk yang diberikan oleh smartphone Oppo maka akan meningkatkan brand image dari smartphone Oppo tersebut. Kedua, kualitas produk secara signifikan berpengaruh positif terhadap keputusan pembelian produk smartphone Oppo di Kota Denpasar. 
Hal tersebut menyimpulkan semakin baiknya kualitas produk yang diberikan smartphone Oppo maka akan meningkatkan keputusan pembelian konsumen terhadap produk smartphone Oppo. Ketiga, brand image secara signifikan berpengaruh positif terhadap keputusan pembelian produk smartphone Oppo di Kota Denpasar. Hal tersebut menyimpulkan semakin baiknya brand image yang diberikan smartphone Oppo maka akan meningkatkan keputusan pembelian konsumen terhadap produk smartphone Oppo. Keempat, brand image mampu memediasi pengaruh kualitas produk terhadap keputusan pembelian produk smartphone Oppo di Kota Denpasar. Hal tersebut menyimpulkan bahwa brand image memediasi pengaruh kualitas produk terhadap keputusan pembelian secara parsial, dengan kata lain brand image memperkuat pengaruh kualitas produk terhadap keputusan pembelian pada produk smartphone Oppo.

Beberapa saran yang dapat disampaikan dalam penelitian ini, antara lain:pihak Oppo sebaiknya lebih meningkatkan kualitas produk smartphone Oppo terutama dalam desain smartphone yang ditawarkannya. Hal yang dapat dilakukan Oppo adalah dengan pengadaan model-model desain smartphone yang mengikuti perkembangan trend jaman sehingga konsumen akan lebih banyak mendapatkan pilihan model smartphone yang dibutuhkannya. Selain itu, pihak Oppo sebaiknya menambahkan fitur-fitur khusus yang hanya dapat ditemukan pada smartphone Oppo seperti fitur aplikasi, kamera, baterai hemat daya, dan lain-lain, sehingga merek smartphone Oppo memiliki keunikan tersendiri yang dapat meningkatkan keunggulan merek smartphone Oppo dibandingkan merek lainnya dan pihak Oppo juga sebaiknya meningkatkan kualitas produk dan menjaga brand image 
yang dimiliki sehingga konsumen merasa lebih yakin dalam mengambil keputusan membeli produk smartphone Oppo dibandingkan merek lainnya.

\section{REFERENSI}

Ago, Gordius., Suharno., Sri Mintarti., Sugeng Hariyadi. (2015). Effect of Product Quality Perception, Trust, and Brand Image on Generic Drug Buying Decision and Consumer Satisfaction of Hospital Patients in East Kalimantan. European Journal of Business and Management, 7 (14),5068 .

Alfred, Owusu. (2013). Influences of Price and Quality on Consumer Purchase of Mobile Phone in the Kumasi Metropolis in Ghana a Comparative Study. European Journal of Business and Management, 5 (1), 179-198.

Amrullah, Artika Romal dan Sasi Agustin. (2016). Pengaruh Kualitas Produk, Harga, dan Citra Merek Terhadap Keputusan Pembelian Honda Beat. Jurnal Ilmu dan Riset Manajemen, 5 (7), 1-15.

Arimbawa, I Gede Sueca dan Ni Wayan Ekawati. (2017). Pengaruh Penerapan Green Marketing Terhadap Citra Merek dan Keputusan Pembelian Produk. E-Jurnal Manajemen Unud, 6 (5), 2582-2608.

Aristyowati, Novida., Maria Magdalena Minarsih., Aziz Fathoni. (2015). Effect of Quality Products, Brand Image and Price Towards Purchase Decision (Studies in Buyer OBH Combi in Pharmacies in Semarang. Journal of Management, 1 (1), 1-15.

Asosiasi Jasa Penyelenggara Jasa Internet Indonesia. (2016). Penetrasi \& Perilaku Pengguna Internet Indonesia. https://www.apjii.or.id/survei2017. Diakses 12 September 2017.

Dewi, Ni Nyoman Ayu Suri Tri Cahyaning dan I Gusti Agung Ketut Gede Suasana. (2014). Pengaruh Kualitas Produk, Citra Merek dan Materialisme Terhadap Loyalitas Merek Pengguna Produk Apple di Kota Denpasar. EJurnal Manajemen Unud, 3 (3), 714-732.

Durrani, Baseer Ali, Msc., Senior Lecturer Danish Iqbal Godil, M-Phil., Senior Lecturer Mirza Uzair Baig, Msc., Senior Lecturer Sana Sajid, Mba. (2015). Impact of Brand Image on Buying Behaviour Among Teenagers. European Scientific Journal, 11 (5), 155-168.

Citra, Tamara dan Suryono Budi Santoso. (2016). Analisis Pengaruh Kualitas Produk dan Citra Merek Terhadap Keputusan Pembelian Cetakan Continuous Form Melalui Kepercayaan Merek (Studi pada Percetakan 
Jadi Jaya Group Semarang). Jurnal Studi Manajemen \& Organisasi, 13 (1), 67-79.

Godey, Bruno., Daniele Pederzoli., Gaetano Aiello., Raffaele Donvito., Priscilla Chan., Hyunjoo Oh., Rahul Singh., Irina I. Skorobogatykh., Junji Tsuchiya., Bart Weitz. (2012). Brand and Country of Origin Effect on Consumers' Decision to Purchase Luxury Products. Journal of Business Research, 65 (2), 1461-1470.

Haryantana, I Putu Gede Handre dam Ni Wayan Ekawati. (2017). Pengaruh Celebrity Endorser, Brand Image, dan Persepsi Kualitas Terhadap Niat Beli Sepeda Motor Honda Scoopy di Kota Denpasar. E-Jurnal Manajemen Unud, 4 (9), 2806-2830.

International Data Corporation. (2018). Smartphone Vendor Market Share, 2017 Q4. https://www.idc.com/promo/smartphone-market-share/vendor. Diakses 11 Maret 2017.

Kominfo.go.id. (2015). Indonesia Raksasa Teknologi Digital Asia. https://www.kominfo.go.id/content/detail/6095/indonesia-raksasateknologi-digital-asia/0/sorotan_media. Diakses 12 September 2017.

Kotler, Philip dan Gary Amstrong. (2011). Dasar - dasar Pemasaran. Edisi Kesebilan. Jilid I. Penerbit PT. Indeks Kel. Gramedia. Jakarta.

Kotler, Philip dan Kevin L. Keller. (2012). Marketing Management Edisi 14. Global Edition. Pearson Prentice Hall.

Laura.S, Netty dan Siska Natalia Siringo Ringo. (2017). Pengaruh Kualitas Produk dan Keunggulan Bersaing Terhadap Keputusan Pembelian Dengan Citra Merek Sebagai Variabel Intervening. Journal of Management and Business Review, 14 (2), 258-284.

Lay-Lee, Karen Lim., Han Kok-Siew., Benjamin Chan Yin-Fah. (2013). Factors Affecting Smartphone Purchase Decision Among Malaysian Generation Y. International Journal of Asian Social Science, Vol.3, hal. 2426-2440.

Momani, Raed Ahmad. (2015). The Impact of Brand Dimension on the Purchasing Decision Making of the Jordanian Consumer for Shopping Goods. International Journal of Business and Social Science, 6 (7), 149168.

Noerchoidah. (2013). Analisis Pengaruh Harga, Kualitas Produk dan Iklan terhadap Brand Image dan Keputusan Pembelian Sepeda Motor Merek Kawasaki. Jurnal WIGA, 3 (1), 49-60. 
Nuraini, Alfiyah dan Ida Maftukhah. (2015). Pengaruh Celebrity Endorser dan Kualitas Produk Terhadap Keputusan Pembelian Melalui Citra Merek Pada Kosmetik Wardah di Kota Semarang. Management Analysis Journal, 4 (2), 171-179.

Nurdianto, Dedi dan Tri Yuniati. (2013). Pengaruh Kualitas Produk dan Citra Sebagai Variabel Intervening Terhadap Keputusan Konsumen Dalam Membeli Motor Honda. Jurnal Ilmu \& Riset Manajemen, 2 (10), 1-24.

Nurhayati, Siti. (2017). Pengaruh Citra Merek, Harga, dan Promosi Terhadap Keputusan Pembelian Handphone Samsung di Yogyakarta. Jurnal Bisnis Manajemen dan Akuntasi, 4 (2), 60-69.

Parasayu, Dinda Annisa dan Widayanto. (2016). Pengaruh Kualitas Produk dan Promosi Terhadap Keputusan Pembelian Indomie Goreng Melalui Brand Image Sebagai Variabel Intervening (Studi Kasus pada Mahasiswa S1 Fisip UNDIP Semarang). Jurnal Ilmu Adminsitrasi Bisnis, 5 (4), 1-10.

Parengkuan, Valentine., Altje Tumbel, Rudy Wenas. (2014). Analisis Pengaruh Brand Imagedan Celebrity EndorsmentTerhadap Keputusan Pembelian Produk Shampo Head and Shoulders di 24 Mart Manado. Jurnal Emba, 2 (3), 1792-1802.

Putra, Made Caesar Surya Dwi Putra dan Ni Wayan Ekawati. (2017). Pengaruh Inovasi Produk, Harga, Citra Merek dan Kualitas Pelayanan Terhadap Loyalitas Pelanggan Sepeda Motor Vespa. E-Jurnal Manajemen Unud, 6 (3), 1674-1700.

Rahi, Samar. (2016). Impact of Customer Value, Public Relations Perception and Brand Image on Customer Loyalty in Services Sector of Pakistan. Arabian Journal of Business and Management Review, 2 (4), 1-6.

Rahim, Azira., Siti Zaharah Safin., Law Kuan Kheng., Nurliyana Abas., Siti Meriam Ali. (2016). Factors Influencing Purchasing Intention of Smartphone among University Student, Procedia Economics and Finance. 37 (4), 245-253.

Rares, Angelina dan Rotinsulu Jopie Jorie. (2015). Pengaruh Harga, Promosi, Citra Merek dan Kualitas Produk Terhadap Keputusan Pembelian Konsumen di Toko Bengkel Gaoel Manada Town Square. Jurnal EMBA, 3 (2),592-604.

Rawung, Dhio Rayen., Sem G. Oroh., Jacky S. B. Sumarauw. (2015). Analisis Kualitas Produk, Merek dan Harga Terhadap Keputusan Pembelian Sepeda Motor Suzuki pada PT. Sinar Galesong Pratama Manado. Jurnal Emba, 3 (3), 1298-1308. 
Rohmah, Siti dan Khuzaini. (2015). Pengaruh Citra Merek, Kualitas Produk, dan Layanan Terhadap Keputusan Pembelian Produk Perhiasan. Jurnal Ilmu dan Riset Manajemen, 4 (5), 1-15.

Rosyid, Aji Normawan., Handoyo Djoko W., Widayanto. (2013). Pengaruh Kualitas Produk, Citra Merek, Harga dan Iklan Terhadap Keputusan Pembelian Sepeda Motor Honda Revo (Studi Kasus pada Konsumen Sepeda Motor Honda Revo Astra Motor Kebumen). Diponegoro Journal of Social and Politic. 5 (3), 1-8.

Ruslim, Archi C dan Ferdinand J. Tumewu. (2015). The Influence of Advertisement, Perceived Price, and Brand Image on Consumer Buying Decision to Asus Mobile Phone. Jurnal EMBA, 3 (3), 393-401.

Saraswati, Agung Ratih dan Ketut Rahyuda. (2017). Brand Image Memediasi Kualitas Produk dan Harga dengan Keputusan Pembelian Smartphone Apple di Kota Denpasar. E-Jurnal Manajemen Unud, 6 (6), 3252-3282.

Sari, Asri Fajar., Aziz Fathoni., Leonardo Budi Hasiholan.(2015). Pengaruh Harga, Kualitas Produk dan Promosi Terhadap Keputusan Pembelian Lemari Es Merek LG di PT. Global Elektronik Banyumanik Semarang. Journal of Management, 1 (1), 22-31.

Sekaran, Uma. (2003). Research Metods For Business. New Jersey : Jhon Willey \& Sons Inc.

Situmorang, Irwanti L., Jushermi, Marhadi. (2017). Pengaruh Kualitas Produk dan Iklan Terhadap Citra Merek dan Keputusan Pembelian Produk Kecantikan Merek Pond's pada Remaja di Kota Pekanbaru. JOM Fekon, 4 (1), 72-86.

Sipayung, Mei Linda dan Asmina Herawaty Sinaga. (2017). Marketing Mix Effect and Quality Product Purchase Decision on Rice Pandaraman in South Tapanuli Region. IOSR Journal of Business and Management (IOSR-JBM), 19 (3), 85-89.

Statista. (2018). Smartphone/mobile phone market share worldwide by vendor 2009 - 2017. https://www.statista.com/statistics/271496/global-marketshare-held-by-smartphone-vendors-since-4th-quarter-2009\%. Diakses 11 Maret 2018.

Sugiyono. (2017). Metode Penelitian Bisnis Pendekatan Kuantitatif Kualitatif Kombinasi \& RND. Bandung. Alfabeta. 
Supangkat, Aditya Hangga dan Supriyatin. (2017). Pengaruh Citra Merek, Kualitas Produk, Harga Terhadap Keputusan Pembelian Tas di Intako. Jurnal Ilmu dan Riset Manajemen, 6 (9), 1-19.

Supriyadi., Yuntawati Fristin., Ginanjar Indra K.N. (2016). Pengaruh Kualitas Produk dan Brand Image Terhadap Keputusan Pembelian. Jurnal Bisnis dan Manajemen, 3 (1), 135-144.

Suryonaningsih, Emi., Patricia Dhiana Paramita., Leonardo Budi Hasiholan. (2016). Effect of Price and Image Brand on Consumer Satisfaction with Buying Decision as Intervening. Journal of Management, 2 (2), 12-23.

Susanti, Christina Esti. (2017). Influence of Social Networks and Social Media toward Satisfaction through Apparel Purchase Decision on Adolescents in East Java. International Journal of Supply Chain Management, 6 (4), 224233.

Tanzila., Ali Akbar Sohail., Nazish Tanveer. (2015). Buying Behavior of Smartphone Among University Student in Pakistan. The International Journal of Business \& Management, 3 (1), 34-40.

Top Brand Award. (2018). Top Brand Index 2018 Fase 1. http://www.topbrandaward.com/top-brand-survey/survey-result/top_brand_index_2018_fase_1. Diakses 12 Maret 2018.

Widyastutir, Sri dan Muhammad Said. (2017). Consumer Consideration in Purchase Decision of SPECS Sport Shoes Product through Brand Image, Product Design and Price Perception. International Journal of Supply Chain Management, 6 (4), 199-207.

Wijaya, Bambang Sukma. (2013). Dimensions of Brand Image : A Conceptual Review from the Perspective of Brand Communication. European Journal Business and Management, 5 (31), 55-65.

Yeboah, Solomon Kofi., Emmanuel Tenakwah Junior., Jennifer Adonteng-Sakyi. (2017). Effect of Brand on Consumer Purchase Decision in the Mobile Telecommunications Industry. Imperial Journal of Interdisciplinary Research (IJIR),3 (8), 683-692. 